\title{
SMN2 Gene
}

National Cancer Institute

\section{Source}

National Cancer Institute. SMN2 Gene. NCI Thesaurus. Code C127867.

This gene plays a role in the modulation of spliceosome formation. 